\title{
REGIONS AND \\ REGIONALISM IN \\ THE UNITED STATES
}




\section{The Contemporary United States}

Series Editors: CHRISTOPHER BROOKEMAN AND WILLIAM ISSEL

PUBLISHED TITLES

Michael Bradshaw

REGIONS AND REGIONALISM IN THE UNITED STATES

Christopher Brookeman

AMERICAN GULTURE AND SOCIETY SINCE THE 1930s

Kenneth Fox

METROPOLITAN AMERICA

Rochelle Gatlin

AMERICAN WOMEN SINCE 1945

William Issel

SOGIAL CHANGE IN THE UNITED STATES 1945-1983

Manning Marable

RACE, REFORM AND REBELLION: THE SECOND

RECONSTRUCTION IN BLACK AMERICA 1945-1982

Leonard Quart and Albert Auster

AMERICAN FILM AND SOCIETY SINCE 1945

FORTHCOMING TITLES

Michael Dunne

AMERICAN FOREIGN RELATIONS SINGE WORLD WAR II

Patrick Renshaw

AMERICAN LABOUR HISTORY, 1935-1981

Sam Rosenberg

AMERICAN ECONOMIC DEVELOPMENT SINCE 1945 


\section{REGIONS AND REGIONALISM IN THE UNITED STATES}

Michael Bradshaw

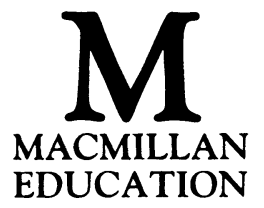


Softcover reprint of the hardcover 1st edition 1988 978-0-333-39861-6

All rights reserved. No reproduction, copy or transmission of this publication may be made without written permission.

No paragraph of this publication may be reproduced, copied or transmitted save with written permission or in accordance with the provisions of the Copyright Act 1956 (as amended), or under the terms of any licence permitting limited copying issued by the Copyright Licensing Agency, 7 Ridgmount Street, London WC1E 7AE.

Any person who does any unauthorised act in relation to this publication may be liable to criminal prosecution and civil claims for damages.

First published 1988

Published by

MACMILLAN EDUCATION LTD

Houndmills, Basingstoke, Hampshire RG21 2XS

and London

Companies and representatives

throughout the world

Typeset by Wessex Typesetters

(Division of The Eastern Press Ltd)

Frome, Somerset

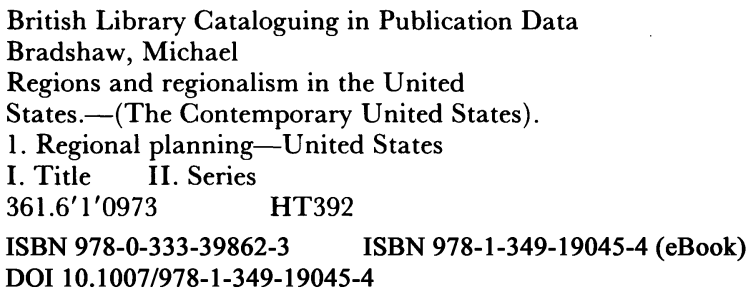

\section{Series Standing Order}

If you would like to receive future titles in this series as they are published, you can make use of our standing order facility. To place a standing order please contact your bookseller or, in case of difficulty, write to us at the address below with your name and address and the name of the series. Please state with which title you wish to begin your standing order. (If you live outside the United Kingdom we may not have the rights for your area, in which case we will forward your order to the publisher concerned.)

Customer Services Department, Macmillan Distribution Ltd Houndmills, Basingstoke, Hampshire, RG21 2XS, England. 


\section{Contents}

Preface vii

Editors' Preface $\quad$ ix

PART I: REGIONAL DIFFERENCES

1 THE SIGNIFICANCE OF REGIONS 3

2 THE ELEMENTS OF REGIONAL

DIFFERENCES IN THE UNITED STATES

3 THE HISTORIC BASIS OF PRESENT

REGIONAL DIFFERENCES IN THE UNITED STATES

4 ONE AMERICA?

PART II: THE CONCERNS OF REGIONALISM

5 'FROSTBELT v. SUNBELT' - A PARTICULAR CASE

6 REGIONS AND RESOURCES IN THE LATE TWENTIETH GENTURY: EAST v. WEST

7 CHANGES IN THE URBAN-INDUSTRIAL ECONOMY: POVERTY AND AFFLUENCE

8 PUBLIC POLICY AND REGIONALISM:

I. TENNESSEE VALLEY AUTHORITY 
9 PUBLIC POLICY AND REGIONALISM: II. THE APPALACHIAN REGIONAL COMMISSION AND OTHER FEDERAL APPROACHES TO REGIONAL PLANNING IN THE 1960s

10 PUBLIC POLICY AND REGIONALISM:

III. URBAN ISSUES

11 CONCLUSIONS: REGIONS AND

REGIONALISM

Bibliography

Index

184 


\section{Preface}

This book sets out to provide a study of regional variations within the United States, and a critique of the significance of the regional concept as applied in expressions of regionalism in the US in the middle and later part of the twentieth century. In working towards this aim, I have had to come to terms with changes in the ways that geographers have viewed, and made use of, regions as units for study. The writing of this book has become something of a personal journey, but it is hoped that not only will it be seen as an account of the 'state of the art', but also that some new contributions are made.

My secondary aim is to link academic studies with the 'practical' decision-making of government and business concerns. It stems from a desire to be involved in informing those decisions, as well as from a wish to understand and explain them. Social scientists have been less successful in providing help to the decision-makers than in venting negative criticisms of what has taken place as a result of public policy. This book, dealing with the academic pursuit of regional studies and the public expression of regional hopes through regionalism, provides an opportunity to bring these aspects of social science together.

The arrangement of the book is determined partly by the personal journey, and partly by the assumption that some readers may be new to a study of the geography or regional study of the United States. The reader is provided with a knowledge of the different parts of the United States, which increases in depth and detail through the book. The logic of the argument followed is designed to examine developments within the field of regional geography, and then to apply the approach to an examination of regionalism within the US. General points are drawn from this study at the end. The publishers have allowed me to include a 
range of maps and diagrams to illustrate the text, and these are used to introduce detailed information instead of expanding the text with long listy descriptions.

No book is merely the product of one person's thinking, although I take responsibility for the views expressed and the manner in which they are developed. I thank the series editors, Chris Brookeman and Bill Issel, for asking me to write the book and for continuing encouragement. A number of American friends who have been closely involved in public policy regionalism in the United States have provided me with insights and information, and have been unstinting in their giving of time for discussion: Mike Wenger, John Whisman and especially Don Whitehead have my grateful thanks. This book has also gained from discussion of some of the issues developed here over a number of years with Professor John Paterson and Dr Roland Allison. Tony Atkin has drawn the diagrams. 


\section{Editors' Preface}

Mention the United States and few people respond with feelings of neutrality. Discussions about the role of the United States in the contemporary world typically evoke a sense of admiration or a shudder of dislike. Pundits and politicians alike make sweeping references to attributes of modern society deemed 'characteristically American'. Yet qualifications are in order, especially regarding the distinctiveness of American society and the uniqueness of American culture. True, American society has been shaped by the size of the country, the migratory habits of the people and the federal system of government. Certainly, American culture cannot be understood apart from its multi-cultural character, its irreverence for tradition and its worship of technological imagery. It is equally true, however, that life in the United States has been profoundly shaped by the dynamics of American capitalism and by the penetration of capitalist market imperatives into all aspects of daily life.

The series is designed to take advantage of the growth of specialised research about post-war America in order to foster understanding of the period as a whole as well as to offer a critical assessment of the leading developments of the post-war years. Coming to terms with the United States since 1945 requires a willingness to accept complexity and ambiguity, for the history encompasses conflict as well as consensus, hope as well as despair, progress as well as stagnation. Each book in the series offers an interpretation designed to spark discussion rather than a definite account intended to close debate. The series as a whole is meant to offer students, teachers and the general public fresh perspectives and new insights about the contemporary United States. 